gradually aroused, and with the many investigators in the field we may trust that the question will be fairly examined with every means and method at our command.

Before the discovery of the germ causation of disease, it was known that an attack of certain diseases effected a longer or shorter natural immunity against those diseases; and in more recent times since the germs of certain diseases have been isolated - and cultivated, those best acquainted with theoretical and practical bacteriology have entertained favorable views concerning the possibility of artificially producing immunity against the diseases cauced by certain germs.

In some diseases immunity can be established by the use of a modified, less virulent form of the germ, but this is not sufficient; more desirable is an immunity and therapeutic action which can be effected without the introduction into the human system of even the modified germ. For these purposes various investigators are experimenting with the so-called toxins, antitoxins and nucleins.

The present knowledge of physiologic chemistry is inadequate to fully explain the physiologic origin and action of these new elements, but it suggests the way, and many are now diligently searching for such antidisease remedies, which may prove to be more worthy the name of specifics than any so-called drugs of the pharmacopoia.

The first of these remedies which has gained at least a temporary recognition by the profession, is Behring's diphtheria antitoxin. Having recently had access to the Library of the Royal College of Surgeons of England, I gathered as fully as possible, statistics upon the use of the anti-diphtheritic serum.

The following table includes most of the serum treated cases which have been reported. The results of some of the most extensive observations are given separately :

\begin{tabular}{|c|c|c|c|c|}
\hline & & $\left|\begin{array}{c}\text { No. Cases } \\
\text { treated } \\
\text { with } \\
\text { serum. }\end{array}\right|$ & $\begin{array}{l}\text { Mortality } \\
\text { in per } \\
\text { cent. }\end{array}$ & $\begin{array}{l}\text { Previous } \\
\text { Mortality } \\
\text { in per } \\
\text { cent. }\end{array}$ \\
\hline $\begin{array}{l}\text { Vierordt, } \\
\text { Ganghofner } \\
\text { Wiederhofer } \\
\text { Kossel } \\
\text { Baginsky (quoted by } \\
\text { Virchow) } \\
\text { Sonnenburg } \\
\text { Aronson } \\
\text { Ranke } \\
\text { Saltmann } \\
\text { Risel , } \\
\text { Roux, Martin and } \\
\text { Chaillou. } \\
\text { Lebreton } \\
\text { Moiztrd . } \\
\text { Washbourn, Goodali, } \\
\text { Card and others. } \\
\text { White. } \\
\text { Withington . . . }\end{array}$ & $\begin{array}{l}\text { Heidelberg } \\
\text { Prague } \\
\text { Vienna } \\
\text { Berlin } \\
\text { Berlin } \\
\text { Berlin } \\
\text { Berlin } \\
\text { Munich } \\
\text { Leipsic } \\
\text { Halle } \\
\text { Paris } \\
\text { Paris } \\
\text { Paris } \\
\text { Jondon } \\
\text { New York } \\
\text { Boston }\end{array}$ & $\begin{array}{r}300 \\
255 \\
231 \\
\\
195 \\
32 \\
80\end{array}$ & $\begin{array}{l}26.0 \\
12.0 \\
14.7 \\
18.6 \\
25.0 \\
16.0\end{array}$ & $\begin{array}{l}51.7 \\
50.0 \\
\\
31.1 \\
42.7 \\
45.0\end{array}$ \\
\hline $\begin{array}{l}\text { Total number of } \\
\text { Average mortality per } \\
\text { Previous average nort } \\
\text { Collet tive report of ot } \\
\text { in different countrie }\end{array}$ & $\begin{array}{l}\text { lses } \\
\text { ent } \\
\text { lity pei cent. } \\
\text { ler observers }\end{array}$ & 2,632 & 16.8 & 42.0 \\
\hline
\end{tabular}

The above table shows a much lower mortality than has ever been generally attainable under former methods of treatment. Those who have used the remedy most extensively, report that the incidental action of the serum seems to be due to avoidable impurities and to the idiosyncrasy of the patient; also that paralysis, albuminuria, lung complications and necessities for operative procedures occur less frequently than under previous methods.

The relatively inexact method of determining the strength of the serum has been a barrier in the way of exact dosage. If the chemist can separate the antitoxin element in a stable form, the dosage may be made more accurate, the administration simplified, and incidental action may be less frequently observed.

With the experience of the past year as a guide, the investigators hope to be able to show greater evidences of the value of serum-therapy. At the Pasteur Institute in Paris, experiments analogous to those with diphtheria, are being made with the virulent streptococci which cause certain severe, acute, inflammatory, suppurative conditions. A horse has been rendered immune against virulent cultures of the streptococci, and its serum is being used with suitable patients.

Dr. Paquin of St. Louis, is meeting with favorable results in his systematic experiments with tubercular antitoxin, and we shall anxiously await further reports upon his work.

Whatever may be our prejudices for or against serum-therapy, we should assist or at least encourage the investigators, and patiently await the development of such facte as will prove the question at issue.

\section{PROFESSOR SENN'S NOVEL PLASTIC REPAIR} OF CONTRACTURE.

\section{BY MAJOR A. C. GIRARD, SURGEON U. S. ARMY.} FT. SHERIDAN, ILL.

The following ingenious method devised by Profes. sor Senn in his clinic at Rush Medical College, to replace scar tissue by sound skin, is well worthy of general notice. Without going into the history of operations tending to repair defecte I will at once proceed to a description of the case:

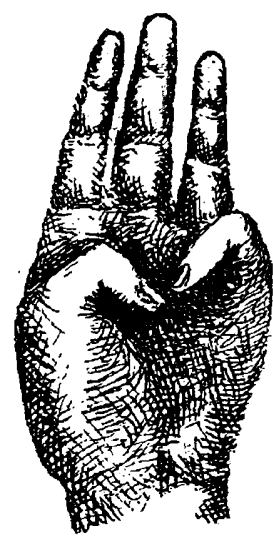

Contractured fingers.

A child about 3 years old had been burned in the left hand some four months before, to such a degree that the cicatrization bound down and flexed the thumb and little finger in an absolutely useless and immovable position. The little finger was liberated by excision of the tendinous bands with comparative facility. To do the same with the thumb would leave a large raw surface. A flap from the anterior chest wall with fixation of the arm, was not feasible, owing to the tender age and consequent lack of cooperation of the child. A flap from the forearm twisted and turned into the palm of the hand, would probably become necrotic and leave matters in a worse shape. Skin grafting would not prevent contracture, and skin transplantation could not be thought of, on account of the lessened vitality of the tissues adjoining the defect. 
After much deliberation, Professor Senn determined on a novel method by dissecting off a flap from the dorsum of the hand, adjoining the thumb, leaving both ends of the flap attached, and slipping it over the thumb into the place vacated by the excised scar.
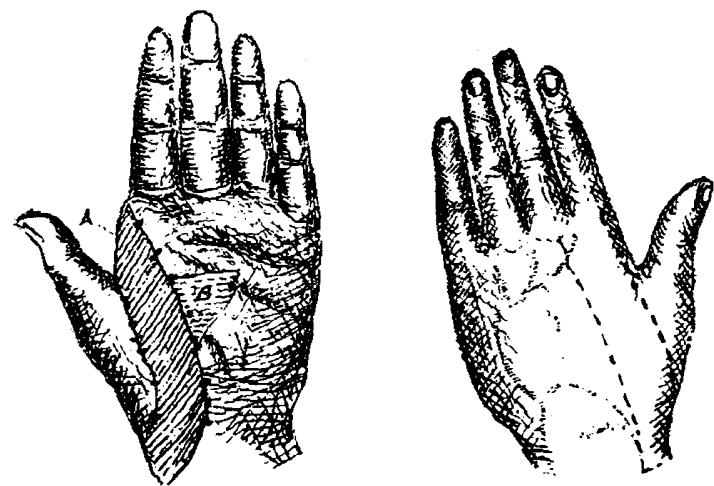

A.-Volar side with flap in place. Dorsal side with outlines of flap. B.-Grafted triangle.

An incision was started from the base of the first finger, carried obliquely upward to near the base of the metacarpal of the thumb; the second incision was parallel to this, about one inch toward the middle finger. The flap was carefully dissected off, preserving the subcutaneous veins. The doubt as to the possibility of slipping it over the bent thumb was soon removed by the ease with which it was made to assume its new place, where it was anchored by two rows of interrupted sutures. A small triangular defect between the flap and the base of the little finger was filled by Thiersch's grafts. The dorsal wound was easily united by interrupted sutures and the usual splint and dressings applied.

At the clinic, a week later, the child was exhibited; the flap had united per primam, the grafts adhered, the dorsal wound was closed and the thumb in its proper place. The prospect of permanent cure of the contracture was assured.

\section{ENEMATA OF WHITES OF EGGS. MEMORANDUM.}

BY JOHN ASHBURTON CUTTER, M.D. NEW YORK.

Albumen of eggs is valuable to feed patients when other forms of nourishment can not be taken or to reinforce other nourishment. I have known patients to take the whites of eighteen egge in one day with evident advantage, in some cases the result appearing almost life-saving.

Exhibition by the mouth is made in three ways: 1 , raw ; 2 , raw with milk; 3 , dropped in boiling water and slightly cooked.

Enemata of uncooked whites I have lately used with decided benefit. Administration by a Davidson hard rubber syringe No. 494, one ounce. Eggs vary in size and weight and should be sold by weight; the albumen of an egg varies in bulk from one-half to one ounce as eggs run.

Drugs can be administered with the raw albumen; sometimes a little laudanum is needed, but rarely, to quiet bowel. Patients state that an enema relieves the faint gone feeling in stomach, and such relief is longer than when the whites are administered by the stomach.

Equitable Building, New York.

\section{PERITONEAL SUPPORTS-(LIGAMENTUM PERITONEI).}

BY BYRON ROBINSON.

PROFESSOR OF GYNECOLOGY POST-GRADUATE SCHOOL.
CHICAGO.

(Continued from page 110.)

The splenic artery perhaps. throws more light on the disposition of the mesogaster than do the gastric and hepatic arteries. The splenic artery arises from the celiac axis and passes at first, slightly downward and then toward the left along the upper border of the pancreas. It is a large spiral artery, but does not project the peritoneum into a very prominent fold, yet the outline of the fold is especially prominent in those animals in which the omentum and transverse colon do not have contact relations, especially at the left end. The prominent feature of the splenic artery in regard to the mesogaster is that the artery in its course lies to the Jeft of the right blade of the mesogaster until it suddenly turns upward to gain access

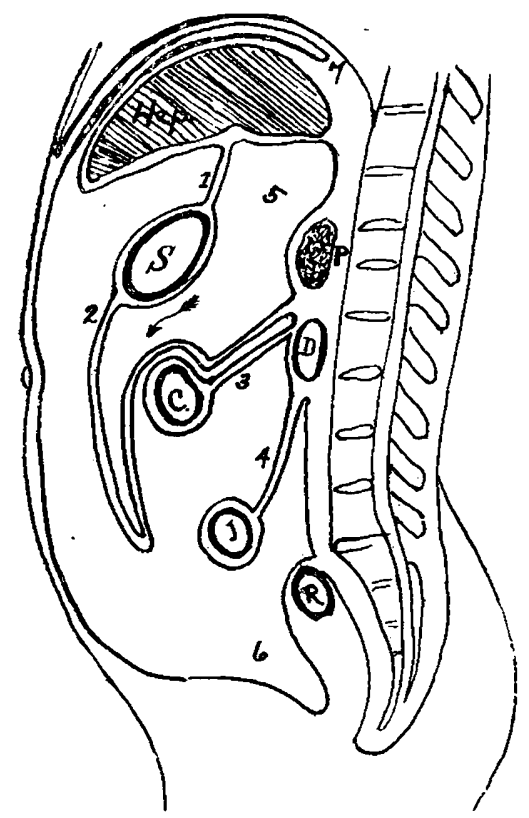

Fig. 22 is copied from the excellent anatom of Prof. Gegeubaur (1884 German edition). It is chiefly to represent the views of an eminent comparative anatomist as regards the transverse colon and omentum. It may be ooserved that his idea is that of coalescence, for his mesocolon transversum consists of four layers (No.3). 1, gastro-hepatic omentum; 5 . lesser omental cavity; $p$. pancreas; 3 , mesocolon transversum ; 4, mesenterium; $d$, duodenum ; $c$, colon; 2 , anterior layers of great omentum; $r$, rectum; 6 , great omental cavity; 7 , reflections of text-book the displacement theory without committing himself to it.

to the space between the blades of the ligamentum gastro-lienalis, but the other equally important feature is that the splenic artery for all its straight horizontal course lies against the posterior abdominal wall, $i . e$. , it does not lie against the left blade of the mesogaster, for that blade has by developmental processes been re-adjusted, displaced, or as some would argue, coalesced. In the process by which the liver forced the stomach to the left and downward and gave origin to the elongated mesogaster and lesser omental bag, the left blade of the mesogaster has been displaced to the left, hence the left and posterior surface of the splenic artery is without a cerous cavity for the most of its trunk, or until it turns upward into the gastro-splenic ligament. The splenic artery being devoid of its serous covering for the length of the chief trunk, on the left side reveals 